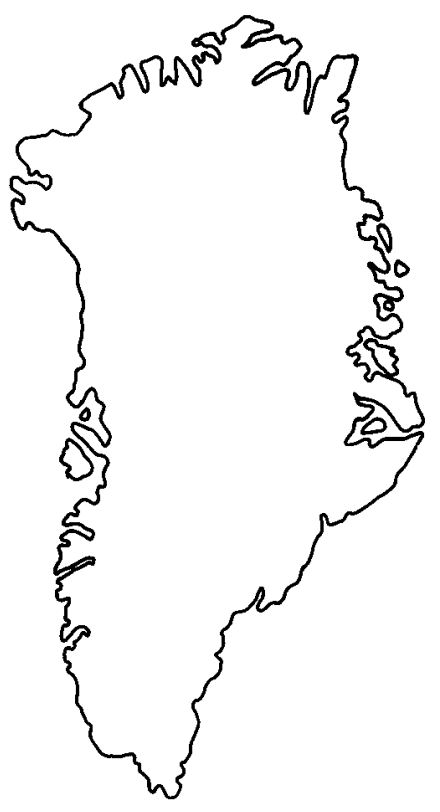

\title{
The Sjælland Fjelde Formation: a new Ordovician formation from eastern North Greenland
}

\author{
J. R. Ineson, J. S. Peel and M. P. Smith
}

The name Sjælland Fjelde Formation is introduced for a varied sequence of shallow-water platform dolomites and dolomitic limestones, about $105 \mathrm{~m}$ in thickness, in Kronprins Christian Land, eastern North Greenland. The new formation lies between the previously described Wandel Valley and Børglum River Formations. Conodont faunas indicate that the Sjælland Fjelde Formation is of Middle to earliest Late Whiterockian (early Middle Ordovician) age and that it can be correlated with the upper part of the Wandel Valley Formation of Peary Land to the north-west.

J. R. I., British Antarctic Survey, High Cross, Madingley Road, Cambridge CB3 OET, U.K.

J. S. P., Grønlands Geologiske Undersøgelse, Øster Voldgade 10, DK-1350 København K, Danmark.

M. P. S., Department of Geology, University of Nottingham, Nottingham NG7 2RD, U.K. Present address:Cambridge Arctic Shelf Programme, Department of Earth Sciences, University of Cambridge, Downing St, Cambridge CB2 3EQ, U.K.

North Greenland is only accessible for geological field work during a short summer field season and geologists have visited the area only sporadically during the last seven decades, frequently under harsh conditions. Reviews of this earlier field work are included in papers by Haller (1971), Dawes (1976), Christie \& Peel (1977), Dawes \& Peel (1981), Dawes \& Christie (1982) and Peel (1982). Early geological observations were often scattered in widely separate localities, with the inevitable result that several local stratigraphic schemes have been established in the literature. Two such local nomenclatures have been formulated in Kronprins Christian Land and in Peary Land, in eastern areas of North Greenland (fig. 1). In the former area an originally embracive Lower Palaeozoic unit, the Centrum Limestone, has been successively refined and sub-divided in a series of papers by Adams \& Cowie (1953), Fränkl (1955), Cowie (1971), Haller (1971) and Scrutton (1975). Shelf sequences in southern Peary Land acquired a different terminology, principally formulated by Troelsen (1949), Jepsen (1971), Mayr (1976) and Christie \& Peel (1977).

As a result of field work carried out throughout the region by the Geological Survey of Greenland in the North Greenland Project 1978-80 it has been possible to develop a single integrated stratigraphic nomenclature for Lower Palaeozoic strata in the Peary Land to Kronprins Christian Land region. Aspects of this integration have evolved in discussions by Peel (1980), Peel et al. (1981), Hurst \& McKerrow (1981), Hurst (1984) and Peel (1986). 
Most stratigraphic names originally employed in the Lower Palaeozoic sequence of Kronprins Christian Land have been abandoned or relegated in status. Terms defined in Peary Land have generally been introduced to the more southerly area. This practice finds justification in both the greater degree of study of the southern Peary Land area and the respective tectonic regimes. Lower Palaeozoic strata in Kronprins Christian Land principally outcrop in the foreland zone of the Caledonian fold belt of East Greenland. As such, outcrops are frequently strongly deformed and repeated by thrusting from the east. Stratigraphic repetition due to thrusting was unfortunately not generally recognised by earlier workers, making difficulties for later recognition of units which were originally only briefly described under physically trying conditions. In contrast the Lower Palaeozoic sequence in southern Peary Land is almost without tectonic disturbance and no structural difficulties complicate the erection of stratigraphic schemes.

Cambrian strata are not proven in Kronprins Christian Land whereas this system is well developed in the southern Peary Land area (Ineson \& Peel, 1980; Peel, 1982, 1986). Ordovician and Silurian carbonate sequences are well represented in both areas, and Hurst \& Surlyk (1982) and Hurst (1984) have revised Silurian sequences from Kronprins Christian Land in terms of Peary Land nomenclature. The Ordovician of southern Peary Land is largely assigned to two formations, the Wandel Valley Formation (Early - Middle Ordovician) and the Børglum River Formation (Middle - Upper Ordovician), although lower beds of the succeeding Tures $\emptyset$ Formation are also of Ordovician age. Both of these principal formations have been recognised in Kronprins Christian Land (Peel, 1980; Peel et al., 1981). However, in the latter area an additional unit is recognised between the Wandel Valley Formation and the Børglum River Formation. This unit is described here and named the Sjælland Fjelde Formation. It is known throughout Kronprins Christian Land and apparently also in Valdemar Glückstadt Land to the west, although the poverty of exposure in the latter area has so far prevented verification of this outcrop pattern.

\section{Sjælland Fjelde Formation}

(new formation)

Name. After Sjælland Fjelde, a range of hills in Kronprins Christian Land, along the eastern shore of Danmark Fjord.

History. The formation forms part of the former Centrum Limestone of Adams \& Cowie (1953). It is possibly equivalent to the Opikina Limestone of Scrutton (1975), although stratigraphic relationships of the units within the now abandoned Centrum Limestone of Adams \& Cowie (1953) are imprecise (Peel et al., 1981; Peel, 1986). It is equivalent to the un-named Ordovician formation of Peel et al. (1981).

Type locality. An isolated small hill on the western side of Sjælland Fjelde, about $4 \mathrm{~km}$ east of Danmark Fjord (figs 1,2).

Thickness. About $105 \mathrm{~m}$ in the type section (fig. 3).

Distribution. Kronprins Christian Land, probably also in Valdemar Glückstadt Land. 


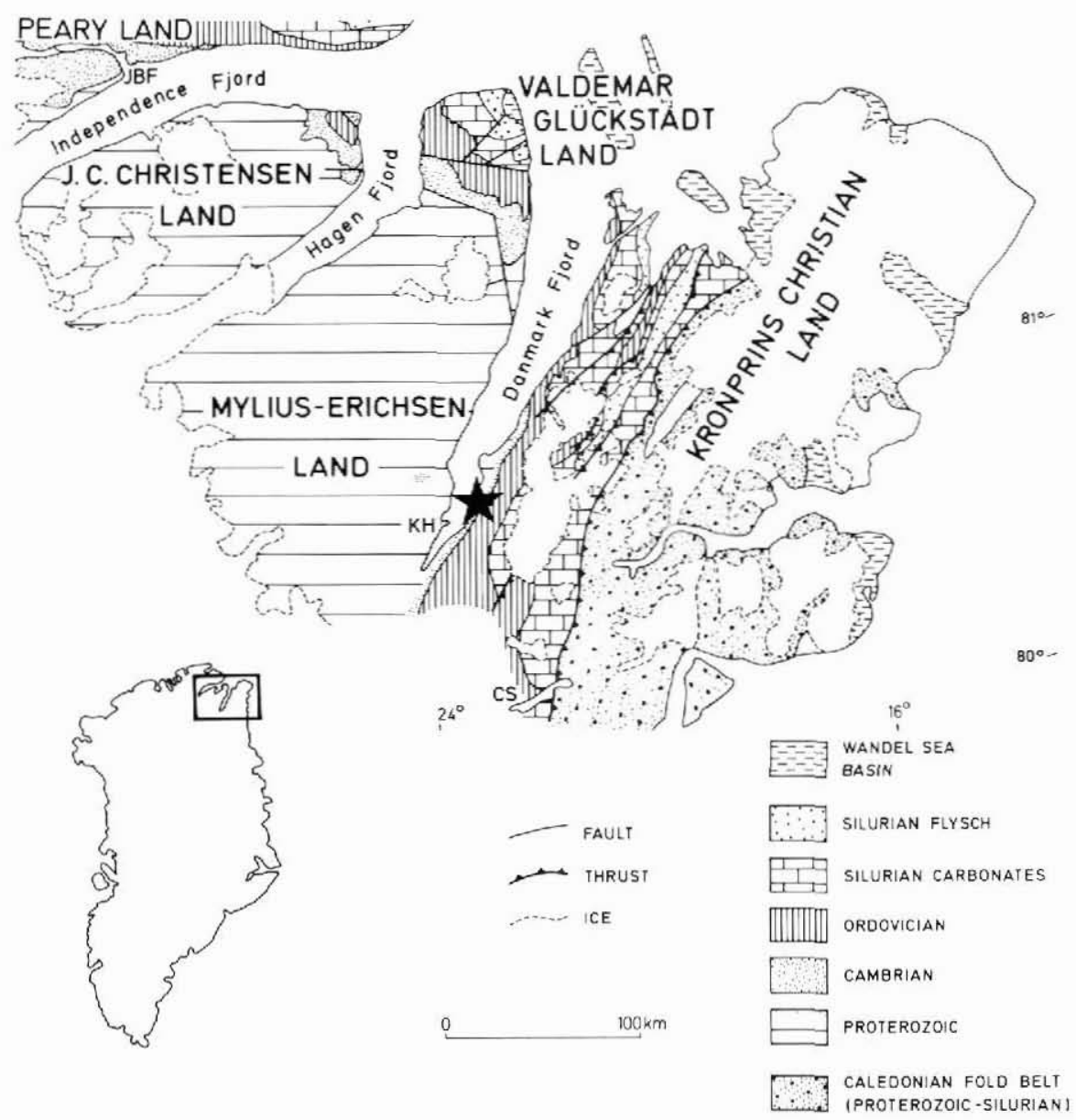

Fig. 1. Eastern North Greenland showing location of the type section of the Sjalland Fjelde Formation (star). CS, Centrum Sø; KH, Kap Holbæk; JBF, Jørgen Brønlund Fjord (after Peel, 1986).

Lithology and subdivision. The formation consists of two distinct members, although these are not formally named. The lower member (thickness $c .55 \mathrm{~m}$ ) appears dark grey-brown weathering and is cliff-forming. The upper member $(c .50 \mathrm{~m})$ is silvery grey weathering and recessive. At the type locality (figs 1,3) the lower member is dominated by dark grey, burrow-mottled, medium to finely crystalline dolomite, with subordinate dolomitic lime mudstone and skeletal grainstone. The lower $20 \mathrm{~m}$ of the formation are composed mainly of limestones, which are argillaceous in the basal $5 \mathrm{~m}$. Bioturbated lime mudstones are dominant, with thin skeletal grainstone laminae and lenticular beds up to $20 \mathrm{~cm}$ thick of fossiliferous flat-pebble conglomerate (fig. 4). The latter beds are composed of tabular, platy clasts of lime mudstone in a skeletal sand matrix that includes fragments of trilobites, brachiopods, gastropods, bryozoans and ostracods. Bed bases are sharp and locally erosional. Many beds show well-developed clast imbrication indicating a dominant flow direction towards the west (fig. 5). The overlying beds of the lower member are mainly burrow-mottled 


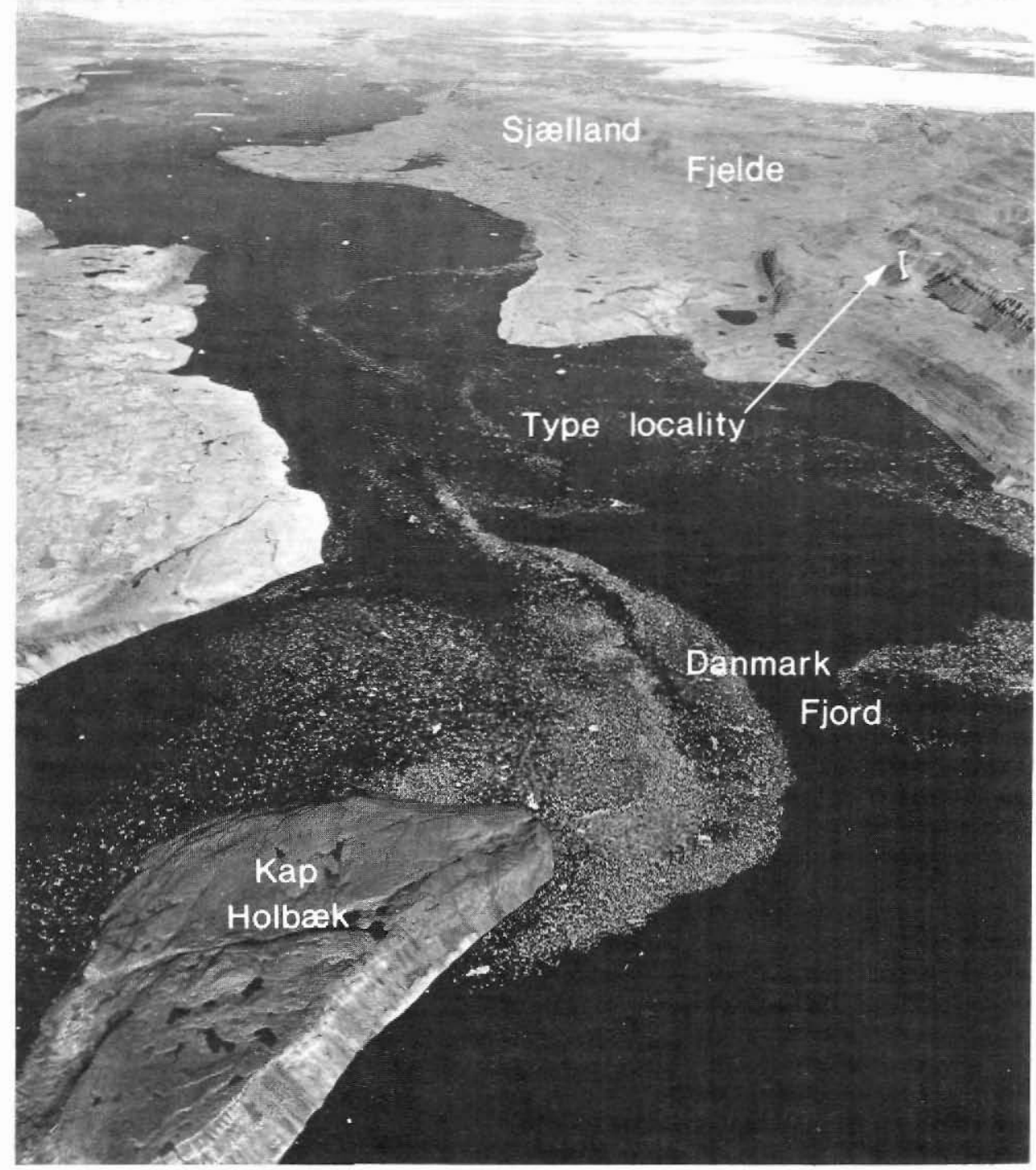

Fig. 2. View to the north-east across Danmark Fjord toward Sjælland Fjelde in western Kronprins Christian Land (photo: Geodætisk Institut, published with permission no. A495/79).

dolomites with occasional impersistent intraformational conglomerates and flaggy, burrowed lime mudstones.

The upper member of the Sjælland Fjelde Formation is characterised by silvery grey weathering, pale grey dolomite which shows both platy and blocky weathering characteristics. Thin intraformational conglomerates occur locally, but irregular, crinkly cryptalgal lamination is the dominant sedimentary structure. Bioturbation is locally in evidence and spar- 


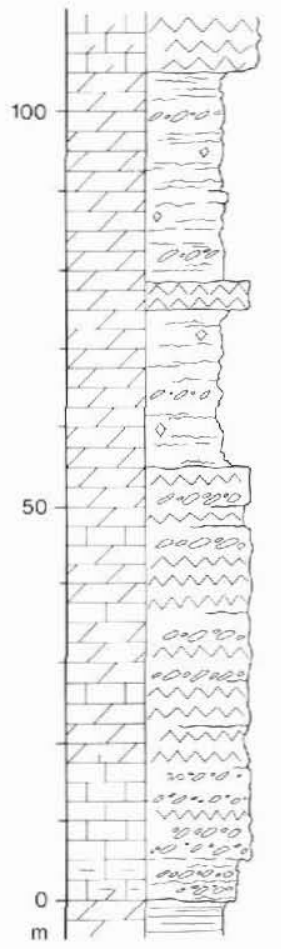

\& 0$$
\text { t. }
$$

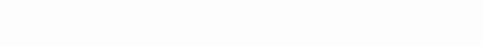

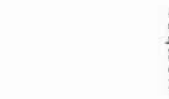

$\backsim \quad \frac{\bar{\Phi}}{3}$

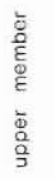
SJELLAND FJELDE FORMATION

2) 9

- - -

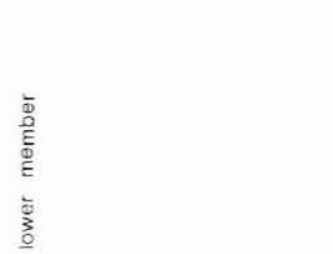

WANDEL VALLEY FORMATION

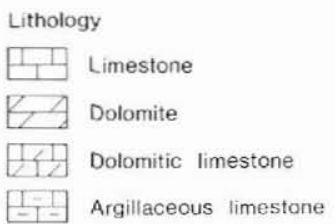
Bioturbation
? weak
21. moderate
ill high

Structures

Planar lamination
Irregular cryptalgal lamination
B Imbricated flat pebble conglomerates
Fossils
is trilobite
$\ominus$ brachiopod
(6) gastropod
$\triangle$ ostracod
- crinoid
M coral
$\nabla \quad$ bryozoan

Fig. 3. Stratigraphic section through the Sjælland Fjelde Formation at its type locality in western Kronprins Christian Land (see fig. 1).

filled vugs and fenestrae are common in places. Dark grey, burrow-mottled dolomite forms a distinctive dark stripe (c. $4 \mathrm{~m}$ thick) about $75 \mathrm{~m}$ above the base of the formation in the type section (fig. 3). Thin coquinas of ostracods (1-10 cm in thickness) occur in the lower $1 \mathrm{~m}$ of this dark interval.

The Sjælland Fjelde Formation shows a similar development elsewhere in Kronprins Christian Land; significant additional features include desiccation cracks, stromatolite 


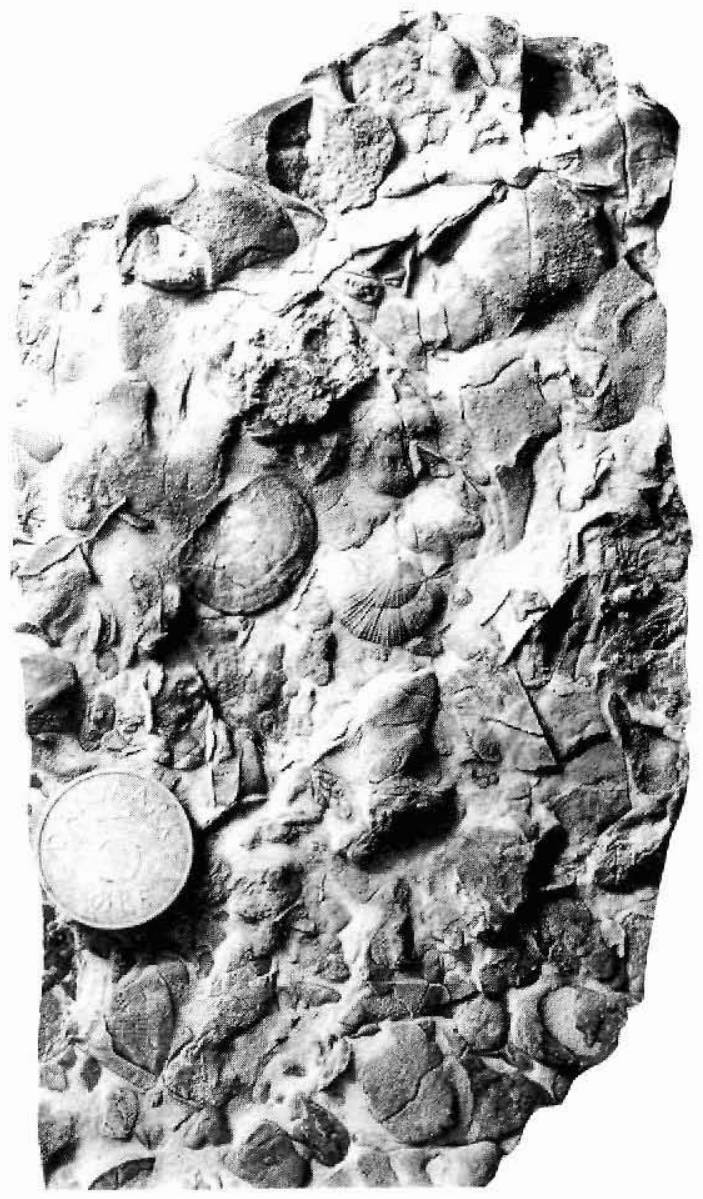

Fig. 4. Bedding plane surface of fossiliferous flat-pebble conglomerate with abundant strophomenacean brachiopods. Lower member, Sjælland Fjelde Formation. GGU sample 274923. Coin is $1.5 \mathrm{~cm}$ in diameter.

domes and, at one locality, halite pseudomorphs (fig. 6). As a mapping unit, the two members of the formation often form a distinctive banded unit below the dark brown, often massive weathering limestones of the overlying Børglum River Formation (fig. 7).

Environmental setting. The Sjælland Fjelde Formation exhibits three main sedimentary facies, described in the previous section. The burrow-mottled dark dolomites and equivalent bioturbated lime mudstones represent lime muds deposited in a low energy, subtidal environment. Bioturbation is ubiquitous in this facies, but shelly fossils are scarce; where present, the fauna is dominated by ostracods. In contrast, the skeletal grainstone laminae and flat-pebble, intraformational conglomerate beds record the passage of episodic, high energy currents. These beds often contain fragments of a rich marine fauna, suggesting derivation from an offshore, open marine location to the east. The association of planar and domal algal lamination, desiccation cracks, bird's eye fenestrae and evaporite pseudomorphs in the pale dolomites suggests deposition in intertidal to low supratidal environments (cf. Wilson, 1975; James, 1979). 


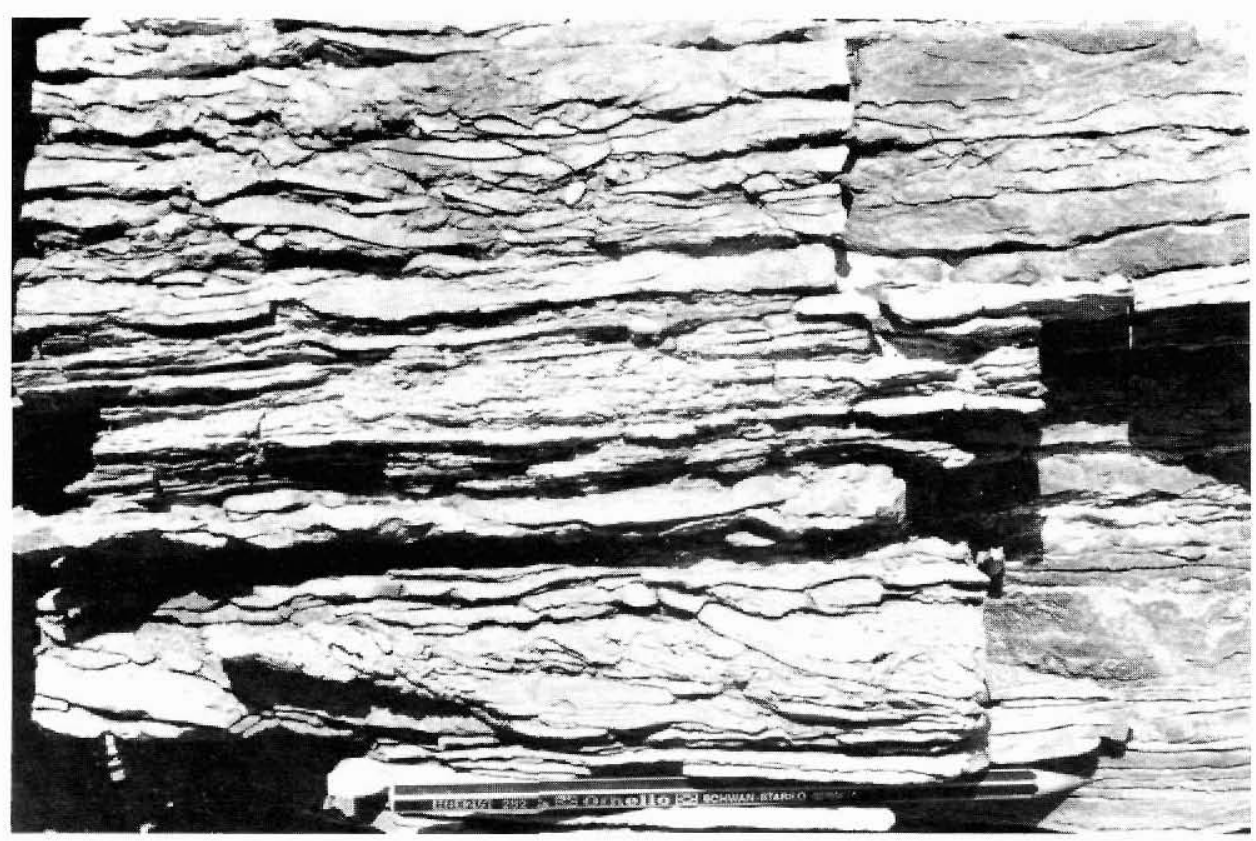

Fig. 5. Imbricated flat-pebble conglomerates interbedded with flaggy burrowed lime mudstones. Note dominant westward flow (right to left). Lower member, Sjalland Fjelde Formation.

Hence the Sjælland Fjelde Formation records deposition on a carbonate platform in shallow subtidal to low supratidal environments. Although predominantly a low energy setting, the flat-pebble conglomerates reflect periodic high energy currents of probable storm origin (cf. Markello \& Read, 1981). The presence of local evaporite pseudomorphs and the scant, low diversity in situ fauna indicates a restricted, locally hypersaline environment. Such an interpretation is compatible with the underlying stromatolitic, mud-cracked, peritidal dolomites of the upper member of the Wandel Valley Formation and the overlying, shallow subtidal, low energy carbonates of the Børglum River Formation.

\section{Conodont biostratigraphy and correlation}

Four samples collected from the upper member of the Wandel Valley Formation and the Sjælland Fjelde Formation in its type section (fig. 8) yielded conodont elements. The lowest sample (GGU 274921) from $32 \mathrm{~m}$ below the top of the Wandel Valley Formation contains a sparse fauna comprising Trigonodus? sinuosus (Mound, 1965) and a new genus and species related to Multioistodus. The new species has been described previously only from the eastern Canadian Arctic Islands (Nowlan, 1976), but T? sinuosus is indicative of an Early Middle Whiterockian (early Middle Ordovician) age in terms of the stages defined by Sweet (1984).

A sample from $3 \mathrm{~m}$ above the base of the Sjælland Fjelde Formation (GGU 274922) yielded an abundant fauna of Middle Whiterockian age (fig. 8). The principal diagnostic 

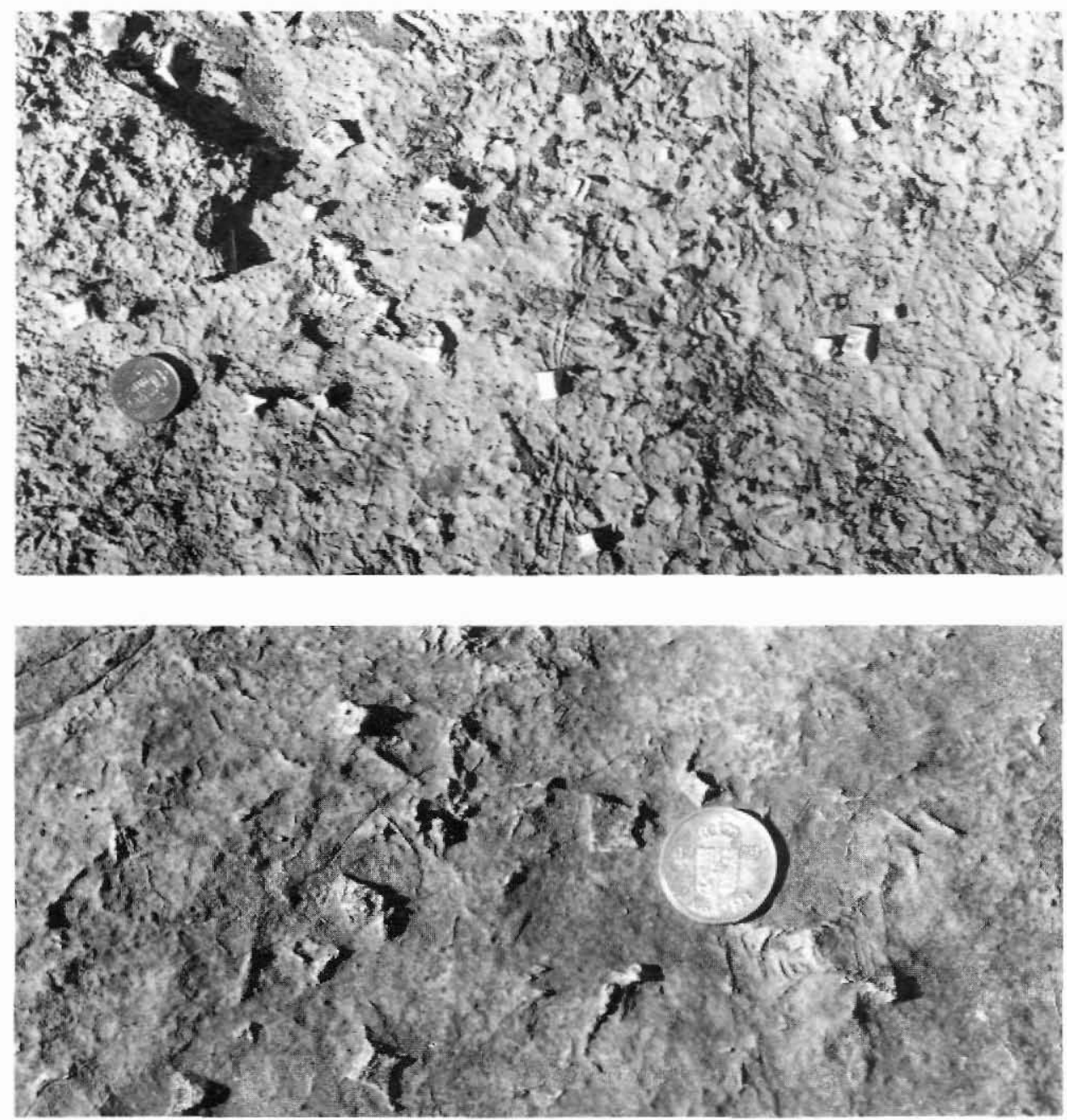

Fig. 6. Halite hopper crystals pseudomorphed by white dolomite within the upper member of the Sjzelland Fjelde Formation. Coin is $2.5 \mathrm{~cm}$ in diameter.

taxon is a species of Phragmodus with a geniculate coniform M element, and twisted posterior processes on the $\mathrm{S}$ elements. Two species of Phragmodus with $\mathrm{S}$ elements of this morphology are found in the Middle Whiterockian and the name P. flexuosus Moskalenko, 1983 has been applied to both. These species occur in stratigraphic succession in Nevada (Harris in Ethington \& Clark, 1982) where an older species with a geniculate coniform M element is replaced by a species, here termed Phragmodus sp. nov., similar in apparatus structure but with a denticulate, dolabrate M element. Moskalenko (1973) erected P. flexuosus as a form taxon for the twisted S elements and, as noted by Ethington \& Clark (1982), it has not been clear whether the apparatus of the type specimens included a coniform or dolabrate $\mathrm{M}$ el- 


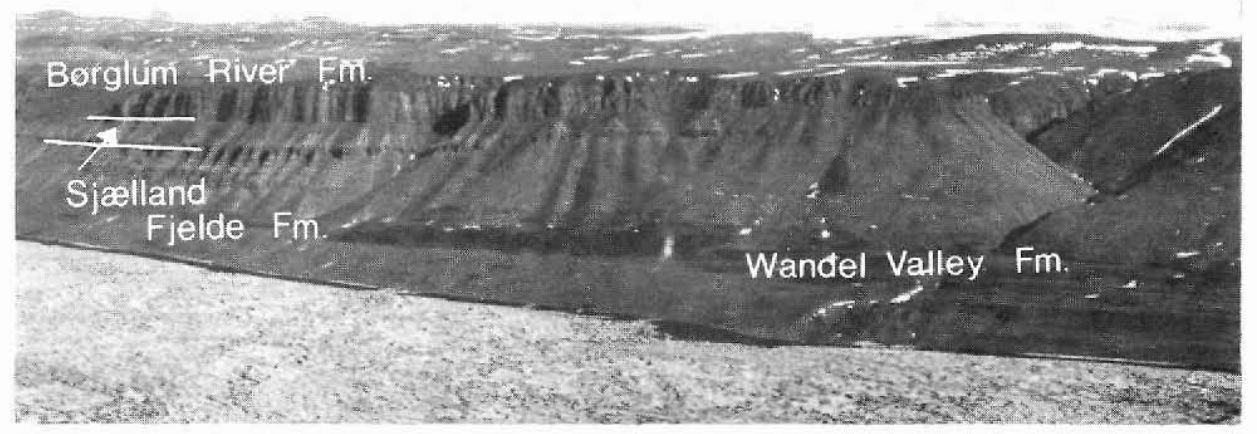

Fig. 7. Western shore of Kronprins Christian Land, some $50 \mathrm{~km}$ north-east of the type locality (see fig. 1), showing the typical style of outcrop of the Sjalland Fjelde Formation. The recessive Wandel Valley Formation is overlain by the dark weathering, cliff-forming, lower member of the Sjælland Fjelde Formation. The succeeding upper member is pale weathering and recessive below the dark weathering, cliff-forming Børglum River Formation.

ement, or both. The tendency has been to reserve P. flexuosus for apparatuses with dolabrate M elements (e.g. Harris et al., 1979). Ethington \& Clark (1982), however, tentatively named the coniform-bearing apparatus $P$. flexuosus and stated that study of the Siberian topotype material was necessary to resolve the problem. Subsequently, the matter has been clarified by Moskalenko (1982) who only included coniform M elements in her reconstruction of $P$. flexuosus from Siberia. In spite of the nomenclatural uncertainty, the biostratigraphic value of these two species has been recognised by Ethington \& Clark (1982) and Sweet (1984), the latter informally naming a $P$. 'pre-flexuosus' Zone (=P. flexuosus in the

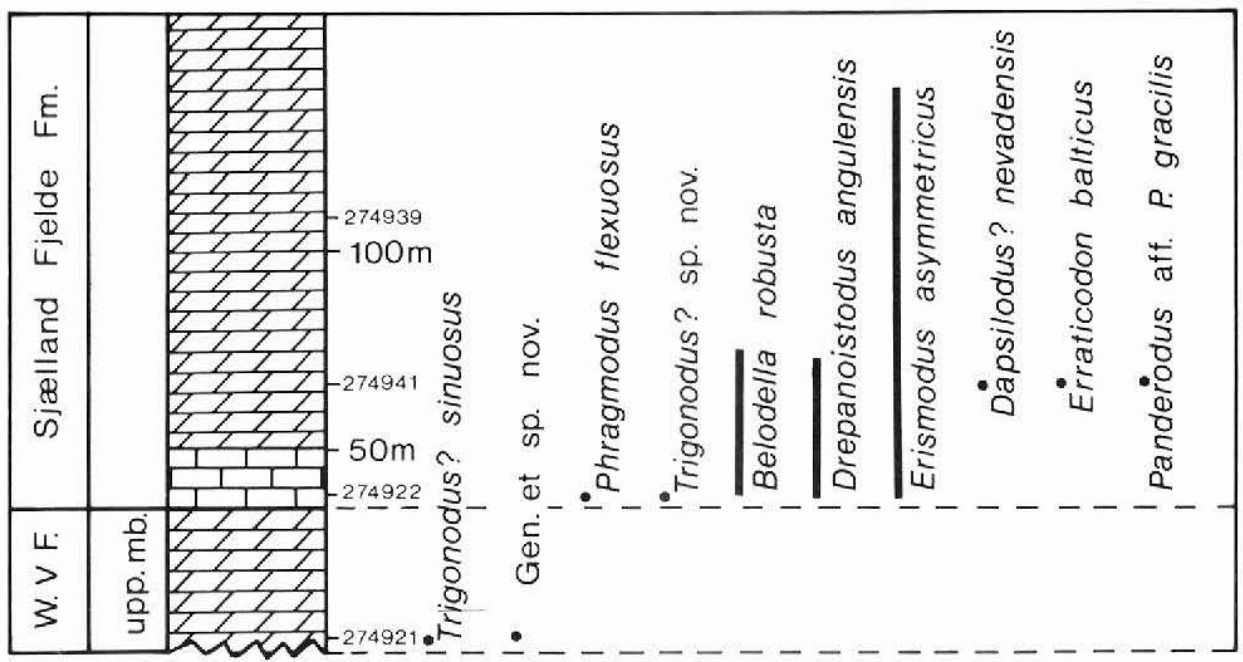

Fig. 8. Distribution of conodonts in four fossiliferous GGU samples from the type section of the Sjælland Fjelde Formation (see fig. 1). 
sense of Moskalenko, 1982). The zone is of late Middle Whiterockian age and equivalent to the E. suecicus Zone to lower P. serra Zone of the North Atlantic Province.

Collections from central Peary Land, north of Jørgen Brønlund Fjord, $200 \mathrm{~km}$ to the north-west (fig. 1) contain $T$ ? sinuosus in samples from $118 \mathrm{~m}$ to $97 \mathrm{~m}$ below the top of the Wandel Valley Formation, although in western Peary Land it is present through to $28 \mathrm{~m}$ below the top. $P$. flexuosus is first recorded $81 \mathrm{~m}$ below the top of the Wandel Valley Formation and ranges through to $58 \mathrm{~m}$ below the top. No diagnostic $M$ elements are then found until 17 $\mathrm{m}$ below the upper boundary, where a dolabrate $\mathrm{M}$ element of Phragmodus sp. nov., the successor to $P$. flexuosus, is present together with S elements. Sweet (1984) considered this species to be introduced at the base of the $P$. friendsvillensis Zone, the lowest zone of the Upper Whiterockian. Belodella robusta Ethington \& Clark, 1982, Erismodus asymmetricus (Branson \& Mehl, 1933), Erraticodon balticus Dzik, 1978 and Trigonodus? sp. nov. are introduced at the same level as P. flexuosus; Drepanoistodus angulensis (Harris, 1962) is also present. The Sjælland Fjelde Formation is correlative with the upper part of the upper member of the Wandel Valley Formation in central Peary Land and, thus, is of Middle to earliest Late Whiterockian age.

Correlation of the Sjælland Fjelde Formation with Ordovician successions in East Greenland is made difficult by the scarcity of $P$. flexuosus in the latter area. However, a single coniform $M$ element of the species has been recovered from approximately $140 \mathrm{~m}$ above the base of the Heim Bjerge Formation (Smith, 1985). This occurrence coincides with the range bases of $B$. robusta and Dapsilodus nevadensis (Ethington \& Schumacher, 1969) and is $10 \mathrm{~m}$ above that of $E$. balticus. The Sjalland Fjelde Formation is thus likely to be coeval with an interval in the lower part of the Heim Bjerge Formation.

Acknowledgements. Philip D. Lane (Keele) and Howard A. Armstrong (Nottingham, now Newcastle) are thanked for companionship in the field during 1980. Peter R. Dawes (GGU) kindly reviewed the manuscript.

\section{References}

Adams, P. J. \& Cowie, J. W. 1953: A geological reconnaisance of the region round the inner part of Danmarks Fjord, Northeast Greenland. Meddr Grønland 111(7), 24 pp.

Christie, R. L. \& Peel, J. S. 1977: Cambrian-Silurian stratigraphy of Børglum Elv, eastern North Greenland. Rapp. Grønlands geol. Unders. 82, 48 pp.

Cowie, J. W. 1971: The Cambrian of the North American Arctic regions. In Holland, C. H. (edit.) Cambrian of the New World, 325-383. London: Wiley Interscience.

Dawes, P. R. 1976: Precambrian to Tertiary of northern Greenland. In Escher, A. \& Watt, W. S. (edit.) Geology of Greenland, 248-303. Copenhagen: Geol. Surv. Greenland.

Dawes, P. R. \& Christie, R. L. 1982: History of exploration and geology in the Nares Strait region. In Dawes, P. R. \& Kerr, J. W. (edit.) Nares Strait and the drift of Greenland: a conflict in plate tectonics. Meddr Grønland, Geosci. 8, 19-36.

Dawes, P. R. \& Peel, J. S. 1981: The northern margin of Greenland from Baffin Bay to the Greenland Sea. In Nairn, A. G. M., Churkin, M. Jr. \& Stehli, F. G. (edit.) The ocean basins and margins 5. The Arctic region, 201-264. New York: Plenum.

Ethington, R. L. \& Clark, D. L. 1982: Lower and Middle Ordovician conodonts from the Ibex area, western Millard County, Utah. Geol. Stud. Brigham Young Univ. 28(2), 160 pp. 
Fränkl, E. 1955: Weitere Beiträge zur Geologie von Kronprins Christians Land (NE-Grönland). Meddr Grønland 103(7), 35 pp.

Haller, J. 1971: Geology of the East Greenland Caledonides, 411 pp. New York: Wiley Interscience.

Harris, A. G., Bergström, S. M., Ethington, E. L. \& Ross, R. J. 1979: Aspects of biostratigraphy of carbonate facies in Nevada and southeast California and comparison with some Appalachian successions. Geol. Stud. Brigham Young Univ. 26(3), 7-44.

Hurst, J. M. 1984: Upper Ordovician and Silurian carbonate shelf stratigraphy, facies and evolution, eastern North Greenland. Bull. Grønlands geol. Unders. 48, 73 pp.

Hurst, J. M. \& McKerrow, W. S. 1981: The Caledonian nappes of eastern North Greenland. Nature, London 290, 772-774.

Hurst, J. M. \& Surlyk, F. 1982: Stratigraphy of the Silurian turbidite sequence of North Greenland. Bull. Grønlands geol. Unders. 145, $125 \mathrm{pp}$.

Ineson, J. R. \& Peel, J. S. 1980: Cambrian stratigraphy in Peary Land, eastern North Greenland. Rapp. Grønlands geol. Unders. 99, 33-42.

James, N. P. 1979: Facies models 10. Shallowing-upward sequences in carbonates. In Walker, R. G. (edit.) Facies models. Geoscience Canada Reprint ser. 1, 109-119.

Jepsen, H. F. 1971: The Precambrian, Eocambrian and early Palaeozoic stratigraphy of the Jørgen Brønlund Fjord area, Peary Land, North Greenland. Bull. Grønlands geol. Unders 96, 42 pp.

Markello, J. R. \& Read, J. F. 1981: Carbonate ramp-to-deeper shale shelf transitions of an Upper Cambrian intrashelf basin, Nolichucky Formation, southwest Virginia Appalachians. Sedimentology 28, 573-597.

Mayr, U. 1976: Middle Silurian reefs in southern Peary Land, North Greenland. Bull. Can Petrol. Geol. 24, 440-449.

Moskalenko, T. A. 1973: Conodonts of the Middle and Upper Ordovician on the Siberian platform. Trudy Akad. Nauk SSSR, Sibirskoe Otdel., Inst. Geol. Geofiz. 137, 143 pp. (in Russian).

Moskalenko, T. A. 1982: Conodonts. In Sokalov, B. S. (edit.) Ordovician of the Siberian platform, key sections on the Kulumbe River, 100-144 \& 182-190. Moscow: Nauka (in Russian).

Nowlan, G. S. 1976: Late Cambrian to Late Ordovician conodont evolution and biostratigraphy of the Franklinian Miogeosyncline, eastern Canadian Arctic Islands. Unpublished Ph.D. thesis, Univ. Waterloo, Ontario.

Peel, J. S. 1980: Geological reconnaissance in the Caledonian foreland of eastern North Greenland with comments on the Centrum Limestone. Rapp. Grønlands geol. Unders. 99, 61-72.

Peel, J. S. 1982: The Lower Paleozoic of Greenland. In Embry, A. F. \& Balkwill, H. R. (edit.) Arctic geology and geophysics. Mem. Can. Soc. Petrol. Geol. 8, 309-330.

Peel, J. S. 1986: Cambrian-Silurian platform stratigraphy of eastern North Greenland. In Gee, D. G. \& Sturt, B. A. (edit.) The Caledonide Orogen: Scandinavia and related areas, 1077-1094. London: Wiley \& Sons.

Peel, J. S., Ineson, J. R., Lane, P. D. \& Armstrong, H. A. 1981: Lower Palaeozoic stratigraphy around Danmark Fjord, eastern North Greenland. Rapp. Grønlands geol. Unders. 106, 21-27.

Scrutton, C. T. 1975: Corals and stromatoporoids from the Ordovician and Silurian of Kronprins Christian Land, Northeast Greenland. Meddr Grønland 171(4), 43 pp.

Smith, M. P. 1985: Ibexian-Whiterockian (Ordovician) conodont palaeontology of East and eastern North Greenland. Unpubl. Ph.D. thesis, Nottingham Univ., 363 pp.

Sweet, W. C. 1984: Graphic correlation of upper Middle and Upper Ordovician rocks, North American Midcontinent Province, U.S.A. In Bruton, D. L. (edit.) Aspects of the Ordovician system. Palaeont. Contr. Oslo Univ. 295, 23-35.

Troelsen, J. C. 1949: Contributions to the geology of the area round Jørgen Brønlunds Fjord, Peary Land, North Greenland. Meddr Grønland 149(2), 29 pp.

Wilson, J. L. 1975: Carbonate facies in geologic history, 471 pp. Berlin, Heidelberg, New York: Springer-Verlag. 